\title{
TRIP10 wt Allele
}

National Cancer Institute

\section{Source}

National Cancer Institute. TRIP10 wt Allele. NCI Thesaurus. Code C52310.

Human TRIP10 wild-type allele is located in the vicinity of 19p13.3 and is approximately 12

$\mathrm{kb}$ in length. This allele, which encodes cdc42-interacting protein 4, plays a role in the mediation of both cellular responses to insulin and endocytosis. 